DOI https://doi.org/10.15589/znp2020.1(479).6

УДК 621.036 .07

\title{
IMPROVEMENT OF TECHNICAL AND ECONOMIC EFFICIENCY OF SHIP BOILER UNITS FOR COMBUSTION OF WATERFUEL EMULSIONS
}

\section{ПІДВИЩЕННЯ ТЕХНІКО-ЕКОНОМІЧНОЇ ЕФЕКТИВНОСТІ СУДНОВИХ КОТЕЛЬНИХ УСТАНОВОК У ПРОЦЕСІ СПАЛЮВАННЯ ВОДОПАЛИВНИХ ЕМУЛЬСІЙ}

\author{
Oleksandr M. Filipshchuk \\ filipschuk5@gmail.com (mailto: filipschuk5@gmail.com) \\ ORCID:0000-0003-4061-7577 \\ Oleg V. Kolbasenko \\ orden2020@gmail.com (mailto: orden2020@gmail.com) \\ ORCID:0000-0001-9460-4558
}

\author{
О. М. Філіпщук, \\ ст. викладач \\ О. В. Колбасенко, \\ аспірант
}

Admiral Makarov National University of Shipbuilding, Mykolaiv

Національний університет кораблебудування імені адмірала Макарова, м. Миколаӥв

\begin{abstract}
The purpose of the study is to increase the technical and economic efficiency of ship boiler units using water emulsions. To improve the reliability of the impact assessment of salt content, the level of cavity treatment and the water content of WFE studies were conducted on a pilot plant.

In order to provide the required level of cavitation processing of WFE, which was estimated by the $\mathrm{pH}$ value at the level of 8,5 and the dispersion at the level of $1 \ldots 2$ microns, the fuel system consists of: from the first contour of the previous cavitation-circulating preparation of the WFE with a hydrodynamic cavitator at a multiplicity of circulation of about 10 and the second contour of the direct preparation and maintenance of the quality of the WFE before the rotary nozzle.

Quality control of combustion of fuel oil and VPE was performed with the help of gas sensors "Gasochrome-3101" and OKSI-5M with relative error at the level of $\pm 5 \%$. The reliability of the fuel oil and TPE consumption is ensured by the passage of the oil and VPE through the same special metering device (measurement accuracy $\pm 1 \%$ ). The consistency of fuel consumption was controlled by the constant temperature of the gas at the exit of the furnace at the level of $1200^{\circ} \mathrm{C}$ (measurement accuracy $\pm 5^{\circ} \mathrm{C}$ ). Combustion of WFE with a salt content up to $180 \mathrm{mg} / \mathrm{l}$ with a water capacity of $25 \ldots 30 \%$ allows to reduce the minimum wall temperature of the heating surfaces to $70^{\circ} \mathrm{C}$ due to the reduction of the low-temperature corrosion intensity up to $0,15 \mathrm{~mm} /$ year opens the possibility to install condensation surfaces in boilers.

Design schemes with the installation of condensing surfaces of economizers, high-temperature heat supply and scrubber are developed, which provides an increase in the depth of utilization in waste-heat boiler by $25 \ldots 30 \%$, efficiency in secondary boilers by $10 \%$ and reduction of thermal emissions into the atmosphere by 1,6 times. Taking into account the saving of pure fuel during the combustion of WFE (up to $8 \%$ in the internal combustion engine, in SB up to $25 \%$ with the use of STER (oil-containing water and oil residues on tankers), during work of SPP fuel economy at the level of $10 \%$ is provided.
\end{abstract}

Key words: water-fuel emulsion; salt content; water content; intensity of low-temperature corrosion; condensation surfaces; depth of utilization; fuel economy; water electrodialysis; integrated use of resources.

Анотація. Мета дослідження - підвищення техніко-економічної ефективності суднових котельних установок, що використовують водопаливні емульсії. Для підвищення достовірності оцінки впливу солевмісту, рівня кавітаційної обробки і водовмісту ВПЕ дослідження були проведені на експериментальній установці. Для забезпечення необхідного рівня кавітаційної обробки ВПЕ, яка оцінювалась за значенням рН на рівні 8,5 і дисперсності на рівні 1-2 мкм, паливна система складається: $з$ першого контуру попередньої кавітаційно-циркуляційної підготовки ВПЕ з гідродинамічним кавітатором при кратності циркуляції близько 10 і другого контуру безпосередньої підготовки і підтримки якості ВПЕ перед ротаційною форсункою. Виконувався контроль якості горіння мазуту і ВПЕ за допомогою газоаналізаторів «Газохром-3101» і ОКСІ-5М із відносною погрішністю на рівні $\pm 5 \%$. Достовірність витрат мазуту і ВПЕ забезпечується проходженням мазуту і ВПЕ через один і той самий спеціальний дозуючий пристрій (точність вимірювання $\pm 1 \%$ ). Сталість витрати палива контролювалось за постійністю температури газів на виході з топки на рівні $1200^{\circ} \mathrm{C}$ (точність вимірювань $\pm 5^{\circ} \mathrm{C}$ ). Спалювання 
ВПЕ із солевмістом до $180 \mathrm{мг/л} \mathrm{із} \mathrm{водомісткістю} \mathrm{25-30 \%} \mathrm{дає} \mathrm{змогу} \mathrm{у} \mathrm{зв'язку} \mathrm{зі} \mathrm{зниженням} \mathrm{інтенсивності}$ низькотемпературної корозії до 0,15 мм/рік знизити мінімальну температуру стінки поверхонь нагрівання до $70^{\circ} \mathrm{C}$ і відкриває можливості встановлювати в котлах конденсаційні поверхні. Розроблені конструктивні схеми з установкою конденсаційних поверхонь економайзерів, гарячого теплопостачання і скрубера, що забезпечує збільшення глибини утилізації в УК на 25-30\%, ККД у допоміжних котлах на 10\% і зменшення теплових викидів в атмосферу в 1,6 раза. 3 урахуванням економії чистого палива при спалюванні ВПЕ (в ДВ3 до 8\%, в ДК до 25\% із використанням ВТЕР (нафтомастиломістких вод і нафтозалишків на танкерах) забезпечується економія палива при роботі СЕУ на рівні $10 \%$.

Ключові слова: водопаливна емульсія; солевміст; водовміст; інтенсивність низькотемпературної корозії; конденсаційні поверхні; глибина утилізації; економія палива; електродіаліз води; комплексне використання ресурсів.

\section{ПОСТАНОВКА ЗАДАЧІ}

Із метою підвищення техніко-економічних показників енергетичних установок застосовуються методи фізико-хімічного регулювання на основі застосування альтернативних палив шляхом зміни фізикохімічних властивостей і складу палив, насамперед, введення води (або пари) і спалювання водопаливної емульсії (ВПЕ).

У зв'язку з більш глибокою переробкою нафти мінеральна частина мазуту негативно впливає на фізико-хімічні процеси в елементах суднових енергетичних установок (СЕУ). Для приготування ВПЕ рекомендується використання прісної води, показники якої не регламентовані. Використання на судні додаткових джерел прісної води на основі мембранних технологій потребує інтенсифікації їх процесів iз метою зменшення витрат електроенергії. Для досягнення ефективного використання ВПЕ в суднових котельних установках необхідне вирішення проблеми рівня кавітаційної підготовки води і самої ВПЕ, впливу солевмісту і водовмісту ВПЕ на рівень техніко-економічних показників.

Практично відсутні дані з допустимого значення і впливу солевмісту ВПЕ на швидкість низькотемпературної (НТК) та високотемпературної корозії (ВТК), а значить, на техніко-економічні показники енергоустановок. Проблеми інтенсивності ВТК і НТК не пов'язуються 3 такою важливою характеристикою, як фізико-хімічні властивості мінеральної частини палива і води, застосовуваної для готування ВПЕ. Можливість використання нафтомастиломістких вод як вторинних теплових енергетичних ресурсів (ВТЕР) також вимагає визначення допустимого солевмісту ВПЕ. Відсутні конкретні дані з кількості і можливості одержання прісної води у процесі використання нафтомастиломістких вод.

У зв'язку зі зниженням продуктивності утилізаційних водоопріснювальних установок (ВОУ) при установці сучасних двигунів внутрішнього згоряння (ДВ3) на суднах використовуються додаткові джерела прісної води на основі мембранних технологій (зворотний осмос, електродіаліз). У разі використання ВПЕ електродіаліз забезпечує можливість комплексного використання його продуктів (ділюату для під- готовки емульсій і католіту для зрошення скруберів). Тому необхідна інтенсифікація процесів в електродіалізних ВОУ з метою зменшення витрат електроенергіï.

Великі діапазони зміни параметрів, що характеризують ефективність спалювання ВПЕ, пояснюються не тільки різними якісними показниками органічного палива і води, але передусім технологією підготовки ВПЕ і необхідним кінцевим значенням характеристик підготовленої ВПЕ.

\section{АНАЛІЗ ОСТАННІХ ДОСЛІДЖЕНЬ І ПУБЛІКАЦІЙ}

Згідно з опублікованими даними для забезпечення роботи суднових енергетичних установок на ВПЕ необхідно включення у склад паливної системи СЕУ технологічного вузла з приготування емульсії. У роботі [1] зазначається, що найбільш стабільні емульсії одержуються у процесі використання віброкавітаційних технологій, які забезпечують триступеневу обробку палива: змішування, диспергування і гомогенізацію. При цьому необхідно враховувати вплив інтенсивності кавітаційних процесів на властивості води і ВПЕ $[2 ; 3]$.

У статті [4] наведені найкращі результати застосування кавітаційних процесів для підготовки спалювання ВПЕ, що засновані на використанні явища кумулятивного удару для поліпшення розпилення мазуту, оремульсії і в перспективі водо-вугільних суспензій в енергетичних котлах. При дослідженнях кавітатора на воді число кавітації $\sigma_{\mathrm{t}}$ в горловині сопла Вентурі варіювалося від 0,8 до 0,05. Для теплових електростанцій навіть при застосуванні легкої кавітації $\sigma_{t} \approx 0,8$ одержано приріст ККД котлів на 2,7\% завдяки поліпшенню процесів горіння і теплообміну внаслідок самоочищення радіаційних і конвективних поверхонь нагріву.

Водопаливні емульсії готуються на основі кавітаційних технологій і представляють собою систему, що включає в себе воду, яка є дисперсною фазою 3 діаметром крапель 0,1-10 мкм, що виключає контакт металевих поверхонь паливної апаратури і стінок паливопроводів із водою [5; 6]. За даними [7], досягнуті розміри крапель на рівні 0,05-0,2 мкм. Застосування водопаливних емульсій не вимагає конструктивних 


\section{ЕНЕРГЕТИЧНЕ МАШИНОБУДУВАННЯ №1-2020}

переробок дизеля і паливної системи котлів і дає змогу помітно поліпшити економічні і екологічні характеристики їх роботи.

В роботі [5] наведені дані про вплив емульсії, що виробляється на основі дизельного палива (ДП) (Кременчуцький НПЗ, Україна) і названа паливом екологічним дизельним, на енергетичні та економічні показники дизеля (витрати палива і потужність автотракторного дизеля 4ЧН 12/14 (СМД-19Т) при роботі з різними концентраціями води і рівнями диспергації. 3 даних навантажувальних характеристик дизеля при рівних значеннях об'ємних циклових подач палива, близьких до максимальної потужності, встановлено, що з урахуванням рівних об'ємних витрат палива номінальна потужність дизеля при роботі на ВПЕ зменшується. Але якщо враховувати витрати тільки ДП (без врахування води і емульгатора), то можна зазначити збільшення потужності дизеля на 5-7\%. Витрата дизельного пального в ВПЕ зменшується мірою зростання вмісту води у ВПЕ, що забезпечує збільшення ефективного ККД дизеля при його роботі на ВПЕ. При однакових витратах дизельного пального потужність дизеля в процесі роботи на ВПЕ зростає на 5-7\%. Найбільш значне зниження витрати дизельного пального в ВПЕ зазначається при 15-25\% вмісті води. Додаткова диспергація (доведення діаметра крапель води до 2 мкм) дає змогу зменшити витрату дизельного пального в ВПЕ на 3,5-4\%. В роботі [6] приведені практично такі ж значення економії палива й індикаторного ККД при спалюванні емульсії з водомісткістю 40\%.

Джерелами прісної води для готування ВПЕ можуть бути опріснена вода утилізаційних водоопріснювальних установок, льяльні води, нафтомастиловмісткі води установок підготовки важких палив (вода після сепараторів палив і масла), стоки санітарно-побутових систем, а також запаси води. При сепарації палив і масел разом із водою й механічними домішками вилучається до 3-4\% горючої високомолекулярної частини палива, що знижує економічність енергетичної установки [6]. Загальна витрата води в процесі промивання і сепарування важких палив становить 10-20\% витрат палива. У разі використання цих вод у вигляді ВПЕ із солевмістом нижче 200 мг/л з'явиться змога додатково економити паливо [8].

У процесі експлуатації танкерів середня частка відмитих нафтозалишків становить до 0,5\% кількості перевезених нафтопродуктів. Допустимий вміст води в нафтозалишках вважається 50\%. Економічні переваги (на прикладі котлів типу КВГ-34К танкера типу «Софія») такого способу використання нафтомастиломістких вод очевидні: в кожен рейс, після якого проводиться мийка вантажних танків, танкер використовує на 100-150 т менше палива (з урахуванням наступної утилізації відмитих нафтозалишків) і тому з'являється змога на 100-150 т збільшити масу вантажу [8].
Розроблена система підготовки ВПЕ на основі мазуту M100 з електрохімічною обробкою води в електролізері з подальшим озонуванням католіту і в процесі обробки ВПЕ у вихровому шарі феромагнітних часток, внаслідок чого відбувається реструктуризація палива, що призводить до зменшення сірки на 29,5\% в разі збільшення вмісту води до 38,8\% [9].

Таким чином, у розглянутих літературних даних не представлені кількісні дані остаточного рівня кавітаційної підготовки води в процесі використання електродіалізу, впливу водовмісту ВПЕ на ефективність горіння і економію чистого палива у ВПЕ, а також впливу солевмісту на рівень низькотемпературної корозії, який визначає можливості використання конденсаційних поверхонь нагрівання з метою використання теплоти абсорбції і конденсації. У стаціонарній енергетиці з метою забезпечення надійності роботи газоходів і димової труби для боротьби з вологістю димових газів при їх низькій температурі, що має місце в процесі встановлення конденсаційних економайзерів [10], застосовуються теплові методи захисту газовідвідного тракту шляхом байпасування (в обхід низькотемпературних поверхонь нагрівання (НТПН)) відхідних газів із високою температурою для підмішування і підвищення температури газів (але при цьому зростає вологість газів і знижується ефективність утилізації теплоти), підмішування гарячого повітря, що зменшує вологовміст відхідних газів (але треба мати у складі установки повітряпідігрівач), застосування спеціального обладнання для підсушки газів, внаслідок чого знижується вологість газів. Установка контактних економайзерів і повітряпідігрівачів внаслідок зволоження дуттьового повітря призводить до збільшення долі $\mathrm{NO}_{2}$, викидів теплоти 3 відхідними газами в 2-3 раза, а викиди оксидів азоту зменшаться в 2 раза.

МЕТА ДОСЛІДЖЕННЯ - підвищення техніко-економічної ефективності суднових котельних установок, що використовують водопаливні емульсії 3 підвищеним водовмістом і корекцією їі складу.

\section{МЕТОДИ, ОБ'ЄКТ ТА ПРЕДМЕТ ДОСЛІДЖЕННЯ}

Об'скт дослідження - вплив на ефективність котельних установок процесів підготовки і використання водопаливних емульсій на основі сірчистих мазутів.

Предмет дослідження - закономірності та показники паливної економічності й утилізації теплоти відхідних газів, що зумовлені режимами підготовки і використання водопаливних емульсій та інтенсивністю низькотемпературної корозії.

\section{Завдання досліджень:}

1) визначити вплив складу мазуту і нафтомастиломістких вод в водопаливних емульсіях різного водовмісту і солевмісту на їхню енергоспроможність 
і зниження рівня теплових викидів з урахуванням інтенсивності низькотемпературної корозії в процесі підготовки і використання водопаливних емульсій в умовах, аналогічних використанню в котельних установках;

2) обгрунтувати необхідність застосування інтенсивної електродіалізної підготовки прісної води і їі жорсткої кавітаційної обробки для підготовки ВПЕ;

3) обгрунтувати підвищення техніко-економічної ефективності суднових установок, що використовують водопаливні емульсії з підвищеним водовмістом корекцією їі складу.

Метод дослідження - експериментально-розрахунковий. 3 метоюпідвищення достовірності оцінки впливу різних факторів (коефіцієнту надлишку повітря, сірки в паливі і особливо солевмісту і рівня кавітаційної обробки ВПЕ і водовмісту ВПЕ) дослідження були проведені на експериментальній установці, що забезпечує сталість параметрів горіння ВПЕ (надлишку повітря, складу і витрати палива, температури газів).

Всі дослідження були виконані при використанні мазуту M40 із вмістом сірки $\mathrm{S}^{\mathrm{r}}=1,8 \%$ при коефіцієнті надлишку повітря $\alpha=1,5$ із використанням однієї проби при проведенні всіх досліджень, що забезпечило однакову концентрацію ванадію в паливі на рівні 0,0014\% і надало змогу визначення рівня впливу вмісту $\mathrm{NaCl}$ у воді і значення допустимого солевмісту ВПЕ.

Паливна система експериментальної установки складається $з$ двох контурів кавітаційно-циркуляційної підготовки: перший контур попередньої підготовки ВПЕ з гідродинамічним кавітатором за кратності циркуляції близько 10 забезпечує дисперсність (на рівні 1-2 мкм), а другий контур безпосередньої підготовки і підтримки якості ВПЕ перед ротаційною форсункою і камерою згоряння.

Показник рівня кавітаційної обробки оцінювалась за значенням $\mathrm{pH}$ (досягнуто $\mathrm{pH}$ на рівні 8,5) і вимірюваннями діаметра крапель води в емульсії під мікроскопом. Діаметр крапель води становив 1-2 мкм.

Контроль якості горіння мазуту і ВПЕ на його основі контролювалась за допомогою хроматографа «Газохром-3101» (вимірювання концентрації $\mathrm{H}_{2}$, $\mathrm{CO}, \mathrm{CH}_{4}, \mathrm{O}_{2}$ з метою оцінки продуктів недопалу і визначення втрати теплоти від хімічного недопалу $\mathrm{q}_{3}$ ) і газоаналізатора ОКСІ-5М із метою визначення концентрації $\mathrm{O}_{2}$ (i, відповідно, коефіцієнту надлишку повітря $\alpha$ при горінні), а також токсичних викидів $\mathrm{SO}_{2}$, $\mathrm{NO}_{\mathrm{x}}$ (окремо $\mathrm{NO}$ i $\mathrm{NO}_{2}$ ). Порогова чутливість цих газоаналізаторів (в об.\%) становить: $5 \cdot 10^{-1}$ по $\mathrm{H}_{2}, 1 \cdot 10^{-3}$ по $\mathrm{CO}$ i $\mathrm{CH}_{4}, \mathrm{SO}_{2}, \mathrm{NO}_{\mathrm{x}}, 2 \cdot 10^{-2}$ по $\mathrm{O}_{2}$. Порівняна погрішність знаходиться на рівні $\pm 5 \%$.

Достовірність витрат мазуту і ВПЕ забезпечується проходженням мазуту і ВПЕ через один і той самий спеціальний дозуючий пристрій (точність вимірювання +-1\%). Витрата палива у всіх дослідах становила 2 кг/год, що забезпечувало постійність значень температур газів. Постійність витрати палива впродовж досліду контролювалась за постійності температури газів на виході з камери згоряння експериментальної установки на рівні $1200^{\circ} \mathrm{C}$ за допомогою спеціальної екранованої порівняної термопари ХА, підключеної до ЕПР-09. Розподіл температур газів за довжиною і поперечним розрізом камери згоряння визначався за допомогою платино-родієвої термопари, що розміщувалась у зонді, який охолоджувався водою. Точність вимірювань температур $\pm 5^{\circ} \mathrm{C}$.

\section{ОСНОВНИЙ МАТЕРІАЛ}

У процесі кавітаційно-циркуляційної підготовки ВПЕ у першому контурі паливної системи експериментальної установки впродовж 10 хв стабілізується значення $\mathrm{pH}$, що характеризує вміст іонів $\mathrm{H}^{+}$у воді ВПЕ, і досягається необхідний рівень диспергації. Якщо зберігати готову ВПЕ, то має місце втрата активності води в підготовленій ВПЕ впродовж 250-300 хв. (знижується значення рН до вихідного рівня) (рис. 1), що знижує якість горіння ВПЕ. Тому підготовка ВПЕ має здійснюватися безпосередньо перед спалюванням (перед форсункою).
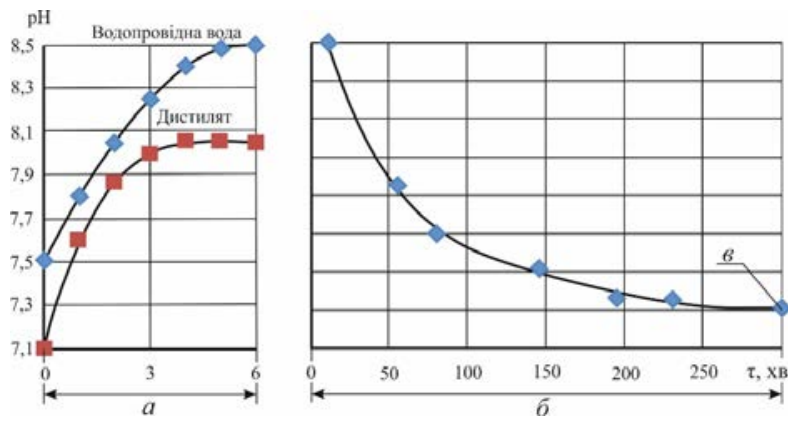

Рис. 1. Зміна рН води при кавітаційно-циркуляційній підготовці:

a) активація води при кавітаційній підготовці ВПЕ; б) термін втрати активності води в підготовленій ВПЕ; в) стабільний стан ВПЕ (відсутність коагуляції крапель води впродовж місяця), але без активності за рН

На основі енергетичних балансів (при однаковому значенні корисного тепловиділення в камері згоряння) в умовах однакових температур газів на виході із камери згоряння на рівні $1200^{\circ} \mathrm{C}$ при спалюванні мазуту i ВПЕ з різним водовмістом (від 2 до 30\%) одержані залежності витрат M40 і ВПЕ та чистого палива в них (дані Національного університету кораблебудування (НУК)). 3 метою оцінки достовірності одержаних даних проведено порівняння (рис. 2) з аналогічними даними Дніпропетровського національного університету (ДНУ) [11], що одержані в процесі спалювання ВПЕ на основі пічного палива в котлі НІІСТУ-5 при підтримці постійної інтегральної температури факела на рівні $1325^{\circ} \mathrm{C}$, що вимірювалась оптичним пірометром 


\section{ЕНЕРГЕТИЧНЕ МАШИНОБУДУВАННЯ № 1 2020}

при зміні водовмісту ВПЕ від 0 до 40\%, і застосуванні емульгатора струминного типу, що забезпечував діаметр крапель 3-3,5 мкм, із байпасним підключенням до паливної системи паливоподачі [11].

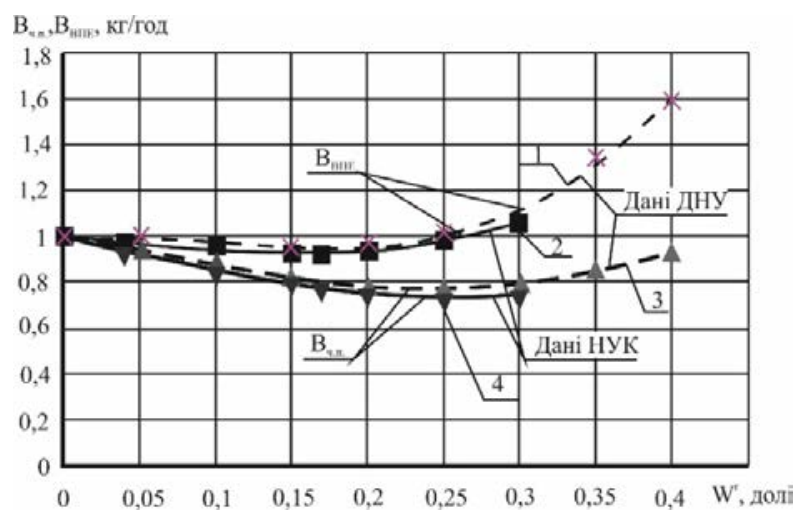

Рис. 2. Порівняння даних з витрат ВПЕ і чистого палива у ВПЕ в теплових агрегатах у перерахунку на 1 кг (на основі теплового балансу):

1 - витрата ВПЕ [дані ДНУ]; 2 - витрата ВПЕ [дані НУК]; 3 - витрата чистого палива у ВПЕ [дані ДНУ]; 4 - витрата чистого палива у ВПЕ [дані НУК]

Проведені експериментальні дослідження показують, що в процесі спалювання в топці котла [11] i в камері згоряння експериментальної установки при забезпеченні постійної температури газів на виході 3 топки економія чистого палива сягає $25 \%$ при спалюванні ВПЕ з водомісткістю 25-27\%.

Згідно з даними [5], максимальна економія чистого палива одержана і при спалюванні ВПЕ з водовмістом 25\% і в камері згоряння (ДВ3) $[5 ; 6 ; 12]$. Тому 3 метою оцінки достовірності одержаних даних і порівняння ефективності спалювання ВПЕ в котлах і ДВЗ на рис. 3 представлено порівняння відношення витрат ВПЕ і витрат чистого палива в ВПЕ, що одержано в НУК і в ДНУ для теплових агрегатів, яке показує, що має місце збіг показників ефективності горіння ВПЕ, що визначене за значенням економії чистого палива у складі ВПЕ для теплових агрегатів і ДВЗ (МОД, СОД i ВОД при $\left.\mathrm{n}=1000 \mathrm{xв}^{-1}\right)$. При $\mathrm{n}=1500 \mathrm{i} \mathrm{n}=2000 \mathrm{xB}^{-1}[5]$ має місце відхилення, що пояснюється погіршенням процесу горіння при таких частотах обертання.

На рис. 4 представлені дані порівняння економічності котлів (теплових агрегатів (ТА)) і ДВЗ. При спалюванні ВПЕ з $\mathrm{W}^{\mathrm{r}}=30 \%$ на основі мазуту M40 в камері згоряння експериментальної установки при забезпеченні максимального рівня кавітаційної підготовки (крива 1) одержані значення на $12 \%$ вищі порівняно 3 режимом роботи, коли відключений перший контур кавітаційно-циркуляційної обробки (крива 2), що вказує на необхідність забезпечення максимального рівня кавітаційної обробки ВПЕ безпосередньо перед форсункою. Залежність значення економічності спалювання ВПЕ на основі пічного палива (крива 3) знаходиться між кривими 1 і 2. Абсолютні значення ККД різних типів ДВ3 (криві 4, 5 і точка 6) знаходяться на рівні 4-9\%. Проведене зіставлення порівняних значень витрат ВПЕ до витрат чистого палива за однакових значеннях водомісткості в межах від 5 до $30 \%$ в котлі і камері згоряння експериментальної установки показали, що вони мають практично однакові значення.

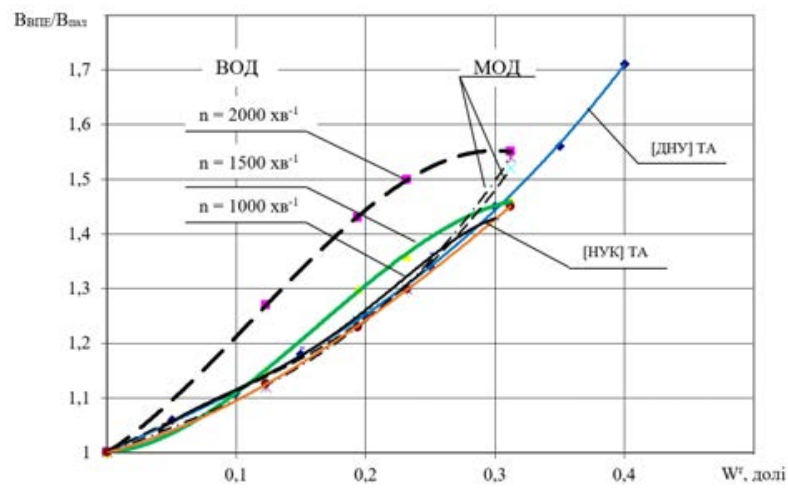

Рис. 3. Відношення витрат ВПЕ і чистого палива залежно від водовмісту $\mathrm{W}^{\mathrm{r}}$ в котлах (дані НУК і ДНУ) і ДВЗ (МОД, СОД і ВОД)

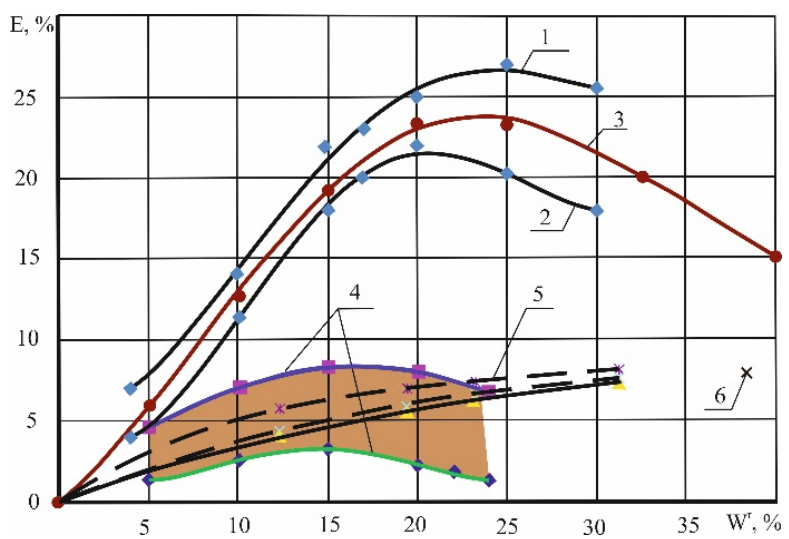

Рис. 4. Економія чистого палива в залежності від водовмісту $\mathrm{W}^{\mathrm{r}}$ в котлах $(1,2,3)$ і ДВ3 $(4,5,6)$ :

1 - при кавітаційній підготовці ВПЕ до рівня $\mathrm{PH}=8,5$ в першому контурі паливної системи; 2- при відключенні першого контуру i значенні $\mathrm{pH}$ на рівні 7,0; 3 - дані Дніпропетровського Національного університету; 4 - дані [12] для СОД і МОД; 5 - дані [5] для ВОД (4ЧН 12/14 (СМД-19Т)); 6 - дані [6] для СОД (12ЧСН 18/20) зі спеціальними плунжерними парами і збільшеним ходом плунжера при підготовці дизеля для спалювання ВПЕ

На основі проведення експериментальних досліджень одержана залежність інтенсивності низькотемпературної корозії (НТК) від температури стінки $[13 ; 14]$ (рис. 5), яка дає змогу визначити мінімальне значення температури стінки низькотемпературних поверхонь нагрівання (НТПН), яка зумовлює можливість більш глибокого використання теплоти відхідних газів і підвищення ККД котлів за рахунок встановлення конденсаційних НТПН у забезпеченні високої надійності їх роботи. 
При спалюванні стандартних сірчистих палив при різних значеннях $\alpha$ i $\mathrm{S}^{\mathrm{r}}$ в паливі (рис. 5) у зв'язку 3 нерівномірністю масопереносу пари сірчаної кислоти при температурах поверхні $\mathrm{t}_{\text {ст }}$ близько $130-140^{\circ} \mathrm{C}$ допустима швидкість низькотемпературної кислотної корозії спостерігається на рівні 0,2 мм/рік, а потім при зниженні $\mathrm{t}_{\text {ст }}$ починається різке зростання інтенсивності НТК із досягненням при $100-110^{\circ} \mathrm{C}$ так званого «кислотного піка» корозії на рівні 1,2 мм/рік, що істотно обмежує величину температури відхідних газів (на рівні $160^{\circ} \mathrm{C}$ ), і у зв'язку з цим величину ККД утилізації енергії продуктів згоряння. Ця властивість рідкого палива $є$ головною причиною невисокої популярності опалювальної техніки, що працює з використанням рідкого палива. Спалювання ВПЕ дасть змогу виправити ситуацію при спалюванні рідкого палива у зв'язку зі зниженням $\mathrm{t}_{\text {ст }}$ in , за якої спостерігається допустима швидкість НТК $\left(\mathrm{K}_{\text {доп }}\right)$ при збільшенні кількості водяної пари у димових газах. У процесі спалювання ВПЕ при температурах стінки в діапазоні 140-70 ${ }^{\circ} \mathrm{C}$ спостерігається незначна за інтенсивністю і рівномірна корозія на рівні 0,15 мм/рік внаслідок пасивації поверхні металу оксидами азоту $\mathrm{N}_{2} \mathrm{O}_{3}(\mathrm{NO}+$ $\mathrm{NO}_{2}$ ) в еквімолярному відношенні [15], що дає змогу більш достовірно оцінювати ресурс роботи металу за середнім значенням швидкості НТК, що знаходилися на основі проведених експериментальних досліджень $[13 ; 14]$.

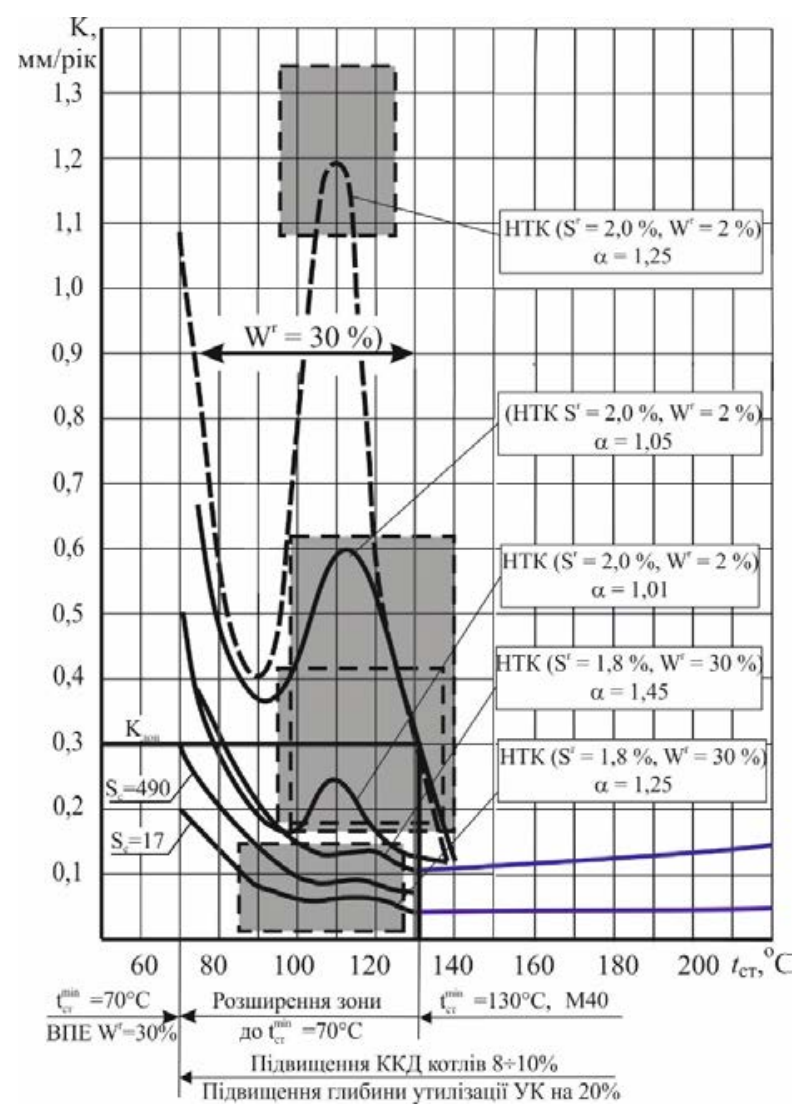

Рис. 5. Можливості підвищення ККД котлів
Таким чином, варто зазначити наявність позитивного впливу $\mathrm{NO}_{\mathrm{x}}$ на проходження фізико-хімічних процесів у котлах. У зв'язку з тим, що абсолютні значення ВТК значно вищі порівняно з НТК [13], допустимий солевміст ВПЕ знаходиться за інтенсивністю ВТК при допустимих значеннях 0,3-025 мм/рік. Отримані результати експериментальних досліджень інтенсивності НТК підтверджуються даними порівняльних технологічних випробувань котельної установки в процесі спалювання чистого товарного палива М100B із коефіцієнтом надлишку повітря 1,3-1,4 і спалювання ВПЕ із вмістом води 30\% [16]. На трубах останнього пакета економайзера після експлуатації котлів КВГ-34К на ВПЕ протягом двох років спостерігалися повна відсутність виразкової і наявність тільки поверхневої рівномірної корозії. ККД котла підвищився на 1-1,5\% (без встановлення конденсаційних НТПН).

Згідно 3 даними рис. 5 при використанні кавітаційно підготовленої ВПЕ $\mathrm{W}^{\mathrm{r}}=30 \%$ солевмістом $\mathrm{S}_{\mathrm{c}} \leq 17$ мг/л мінімальне значення $\mathrm{t}_{\text {ст }}$ min низькотемпературних поверхонь допоміжних і утилізаційних котлів становить $70^{\circ} \mathrm{C}$ (рис. 5), що дає змогу знизити температуру відхідних газів $\vartheta_{\text {віл }}^{\min }$ до $90-100^{\circ} \mathrm{C}$ при температурному натиску $\Delta \mathrm{t}=20-30^{\circ} \mathrm{C}$ (замість $150-160^{\circ} \mathrm{C}$ при спалюванні мазуту з $\mathrm{W}^{\mathrm{r}}$ до $2 \%$ ). При використанні ВПЕ $3 \mathrm{~S}_{\mathrm{c}}=490$ мг/л мінімальне значення $\mathrm{t}_{\text {ст }}{ }^{\min }=80^{\circ} \mathrm{C}$ i тому $\vartheta_{\text {від }}^{\min }=100-110^{\circ} \mathrm{C}$ (рис. 5). В умовах зниження $\Delta \mathrm{t}$ до $10^{\circ} \mathrm{C}$ температура відхідних газів знижується до $80^{\circ} \mathrm{C}$, що зменшує величину теплових викидів (але при цьому зростають габаритні показники котлів).

Розширення зони використання температур tстmin і $\vartheta_{\text {віл }}^{\min }$ забезпечує зниження величини теплових викидів за допомогою утилізаційних котлів в 1,6 раза і дає можливість підвищення ККД допоміжних котлів на $8-10 \%$ залежно від значень надлишку повітря $\alpha$ в процесі установки конденсаційних низькотемпературних поверхонь нагрівання.

Проведені дослідження інтенсивності НТК дали змогу розробити конкретні схеми допоміжних котлів для спалювання ВПЕ. У процесі спалювання стандартних сірчистих мазутів для підвищення ККД котлів встановлюються конвективні поверхні (економайзер, повітряпідігрівач) із tстміп вище $130^{\circ} \mathrm{C}$ (рис. 6,a).

Оскільки при спалюванні ВПЕ з $\mathrm{W}^{\mathrm{r}} \approx 30 \%$ значення $\mathrm{t}_{\text {ст }}{ }^{\min }$ знаходиться на рівні $70^{\circ} \mathrm{C}$ (рис. 5), з'являється змога встановити додатково до сухої поверхні (рис. 6, a) конденсаційну поверхню економайзера (рис. 6, б), що забезпечує конденсацію частини пари $\mathrm{H}_{2} \mathrm{SO}_{4}$ i забезпечує підвищення ККД допоміжних котлів на $8-10 \%$ (в утилізаційних котлах забезпечується можливість підвищення глибини утилізації до 65\%, що призведе до зменшення рівня теплових викидів в 1,6 раза). Але при цьому не забезпечується конденсація водяної пари, концентрація якої в газах у процесі спалювання ВПЕ значно більша. Для забезпечення процесу конденсації водяної пари при $\mathrm{t}_{\text {ст }}$ меншої $53^{\circ} \mathrm{C}$ необхідно використан- 


\section{ЕНЕРГЕТИЧНЕ МАШИНОБУДУВАННЯ № 1 2020}

ня поверхні нагріву з нержавіючої сталі. Тоді конвективні поверхні котлів будуть складатися з сухої частини (при $\mathrm{t}_{\text {ст }}$ до $\left.130^{\circ} \mathrm{C}\right)$, конденсаційної частини для конденсації $\mathrm{H}_{2} \mathrm{SO}_{4}$ (при $\mathrm{t}_{\text {ст }}$ до $70^{\circ} \mathrm{C}$ ), а також конденсаційної частини 3 нержавіючої сталі для конденсації водяної пари (при $\mathrm{t}_{\text {ст }}$ до $30-50^{\circ} \mathrm{C}$ ) (рис. 6, в) у процесі спалювання ВПЕ. Утилізація прихованої теплоти конденсату дає змогу досягти майже стовідсоткового значення ККД при його розрахунку по $\mathrm{Q}_{i}^{\mathrm{r}}$ (нижчій теплоті згоряння). У зв'язку з тим, що в комплексній технології пропонується застосування скруберних технологій, можна скористатися змогою забезпечити конденсацію $\mathrm{H}_{2} \mathrm{O}$ у скрубері. Тоді замість конденсаційної поверхні 3 нержавіючої сталі рекомендована установка скрубера 3 насадкою (рис. $6,2)$, яку можна і необхідно виконати з некорозійного матеріалу (кераміка, кислотостійка пластмаса).

Конструктивні рішення установки теплообмінних поверхонь у скрубері представлені на рис. 7 [15]. Насадка скрубера зрошується тим самим розчином католіту, що активований у кавітаторі електродіалізного апарату для інтенсифікації процесу абсорбції. Температура цього католіту має бути на рівні температури забортної води - обов'язково нижче температури точки роси водяної пари, що знаходиться в димових газах. Під час спалювання ВПЕ з $\mathrm{W}^{\mathrm{r}}=30 \%$ iï значення знаходяться на рівні $50-53^{\circ} \mathrm{C}$ (парціальний тиск водяної пари на рівні 15 кПа). В цьому випадку буде забезпечена конденсація водяної пари газів, що буде (додатково до тепло- ти абсорбції) супроводжуватися виділенням великої кількості теплоти. Внаслідок цього вода на виході 3 насадки після перемішування 3 потоком газів підігріється до $80-90^{\circ} \mathrm{C}$ (рівень температури забезпечується регулюванням витрати католіту на зрошення насадки).

У технології пропонуються додатково два можливі варіанти виконання операції підсушки газів в газоході.

Периий варіант. У разі спалювання в дизель генераторах (ДГ) малосірчистого палива (3 $\left.\mathrm{S}^{\mathrm{r}}<0,5 \%\right)$ необхідно використати теплоту цих газів задля підсушки димових газів після інших агрегатів СЕУ (головні двигуни, допоміжні котли). У процесі підсушки газів після скрубера вихлопними газами від ДГ зникне конденсат на внутрішній поверхні газоходів після скрубера, що знизить інтенсивність корозії цих поверхонь і забезпечить надійність і довговічність їх експлуатації.

Для того, щоб збільшити глибину утилізації теплоти вихлопних газів ДГ, у камерах глушників розміщуються поверхні підігріву води для котлів і для системи гарячого водопостачання, що забезпечить економічність СЕУ загалом шляхом повної утилізації теплоти газів головних двигунів, допоміжних котлів і збільшення глибини утилізації вихлопних газів ДГ.

Другий варіант. У разі спалювання в ДГ сірчистих палив із $\left(\mathrm{W}^{\mathrm{r}}=2 \%\right)$ або $\mathrm{BПЕ}\left(\mathrm{W}^{\mathrm{r}}=30 \%\right)$ можлива підсушка газів, яка проводиться за рахунок теплоти гарячої води, що одержана в підігрівачі системи гарячого водопостачання (рис. 7).

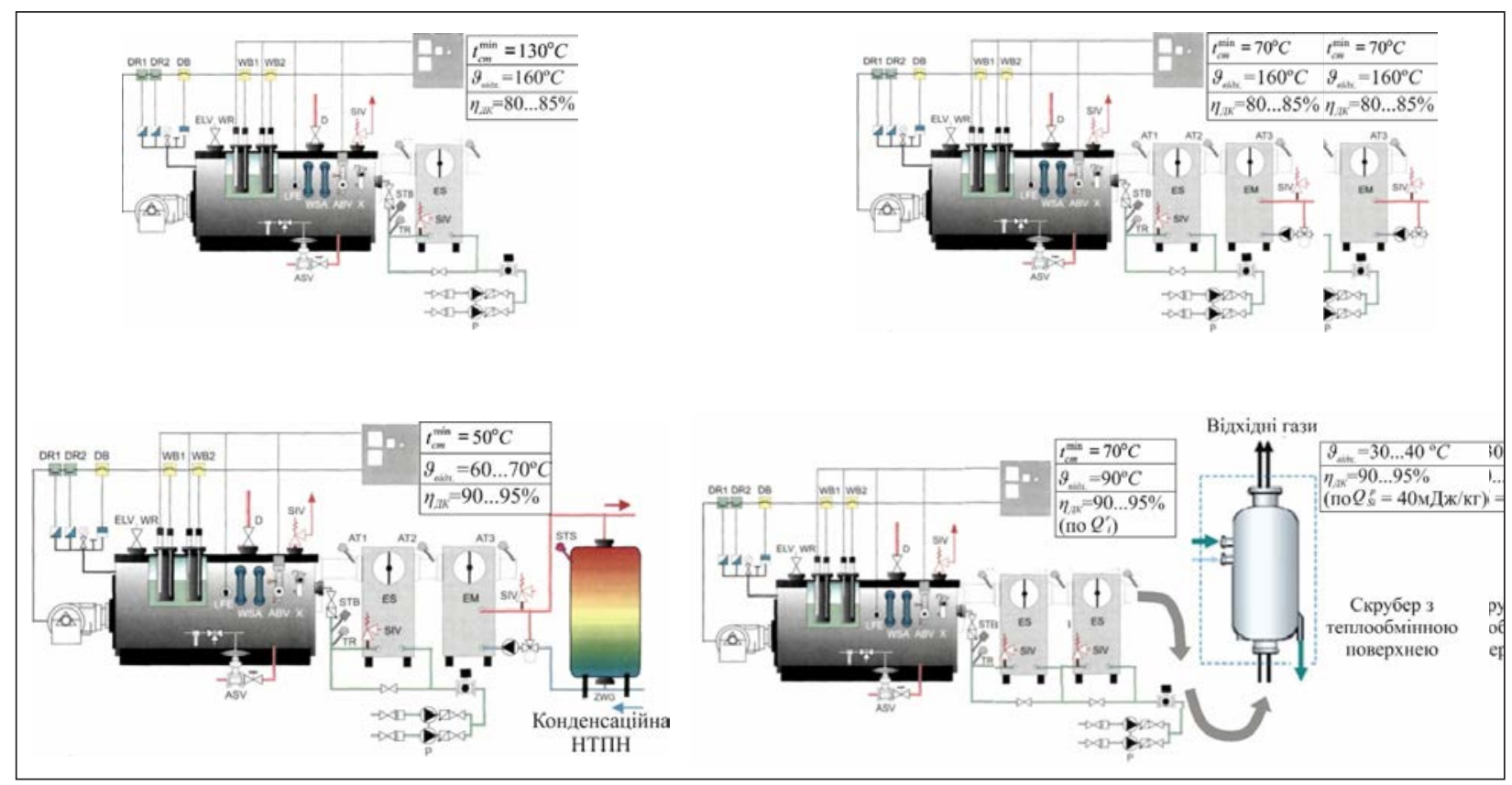

Рис. 6. Конструктивні схеми допоміжних котельних установок:

$a$ - із сухим економайзером, $\mathrm{t}_{c m} \min =130^{\circ} \mathrm{C}, \vartheta_{\text {вidx }}=160^{\circ} \mathrm{C} ; \sigma-$ із сухим економайзером і конденсаційною НТПН для конденсації пари $\mathrm{H}_{2} \mathrm{SO}_{4}, \mathrm{t}_{c m} \min =70-80^{\circ} \mathrm{C}, \vartheta_{\text {відx }}=90^{\circ} \mathrm{C} ;$; - із сухим економайзером і конденсаційною НТПН для конденсації пари $\mathrm{H}_{2} \mathrm{SO}_{4}$ i $\mathrm{H}_{2} \mathrm{O},=50^{\circ} \mathrm{C}, \vartheta_{\text {вidx }}=60-70^{\circ} \mathrm{C} ; 2-$ із сухим економайзером і конденсаційною НТПН для конденсації пари $\mathrm{H}_{2} \mathrm{SO}_{4}$ i скрубером для конденсації водяної пари, $\mathrm{t}_{\text {вidx }}=30-40^{\circ} \mathrm{C}$ 


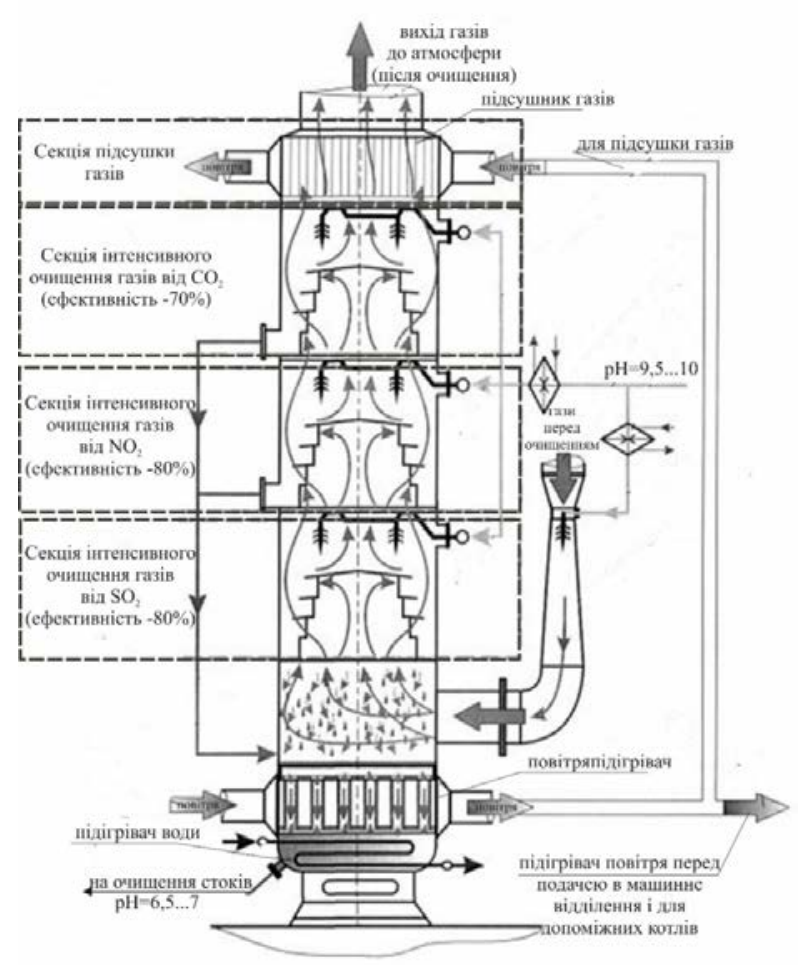

Рис. 7. Схема три секційного мокрого скрубера з підігрівом повітря і підсушкою газів гарячим повітрям

Таким чином, застосування скруберних технологій дасть змогу забезпечити майже 100-відсоткову утилізацію теплоти конденсації пари сірчаної теплоти і водяної пари при надійній роботі конденсаційних поверхонь котлів і їх газоходів, а також газоходів до і після скруберів.

Використання електродіалізного опріснення (ЕДО) забортної води для підготовки води необхідної якості для ВПЕ уможливлює комплексне використання продуктів цієї технології: ділюату у схемі - для кавітаційного приготування ВПЕ, а католіту - для зрошення скруберів, що уможливлює використання теплоти конденсації пари $\mathrm{H}_{2} \mathrm{SO}_{4}, \mathrm{H}_{2} \mathrm{O}$ і забезпечує підвищення еколого-економічних показників енергетичних установок. Задля підвищення ефективності ЕДО пропонується установка додаткових електродів у міжмембранному просторі апарату, на який одержано патент [17].

Як показали результати досліджень [18], установка додаткових електродів із подачею на них незначного потенціалу (на рівні 5-6 В), що значно менше потенціалу, що підводиться на зовнішні електроди до $50 \mathrm{~B}$, дає змогу забезпечити підвищення коефіцієнту виходу по струму на 25\%. Економічне використання ЕДО найбільш ефективне за продуктивності додаткової знесолювальної установки до 10 м³/год, що менше необхідних витрат на опріснення на любих типах суден і навіть при їх водотонажності на рівні 200 000-300 000 т (рис. 8). За базу порівняння (БП) прийнято значення вартості води (крива 1) за продуктивності ВОУ $5 \mathrm{~m}^{3} /$ год.

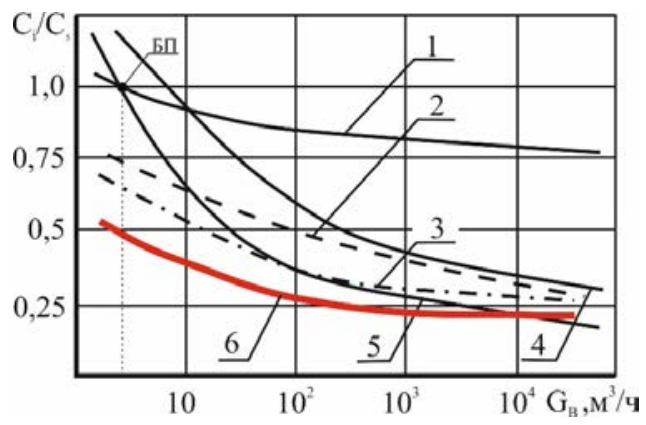

Рис. 8. Залежність відносного значення вартості знесоленої води від продуктивності Gв системи водопідготовки знесолення:

1 - на іонообмінних фільтрах; 2 - в осмотичних модулях та іонообмінних фільтрах; 3 - в електродіалізних апаратах та іонообмінних фільтрах; 4 - у випаровувачах; 5 - в осмотичних модулях та випаровувачах; 6-в електродіалізних апаратах із додатковими електродами

На основі проведених досліджень з урахуванням статистичних даних із витрат палива, води для різних типів суден (на прикладі танкерів та нафторудовозів) побудовані залежності витрат палива при спалюванні ВПЕ і економія паливоенергетичних ресурсів, яка складається з 8\% економії палива в ДВ3 (головні двигуни та дизель генератори) $[5 ; 6 ; 12], 3$ 25\% економії палива в допоміжних котлах, а також за рахунок використання ВТЕР: нафтозалишків - 0,5\% дедвейту танкерів і 0,4\% витрати палив головних двигунів і ДГ при сепарації (рис. 9).

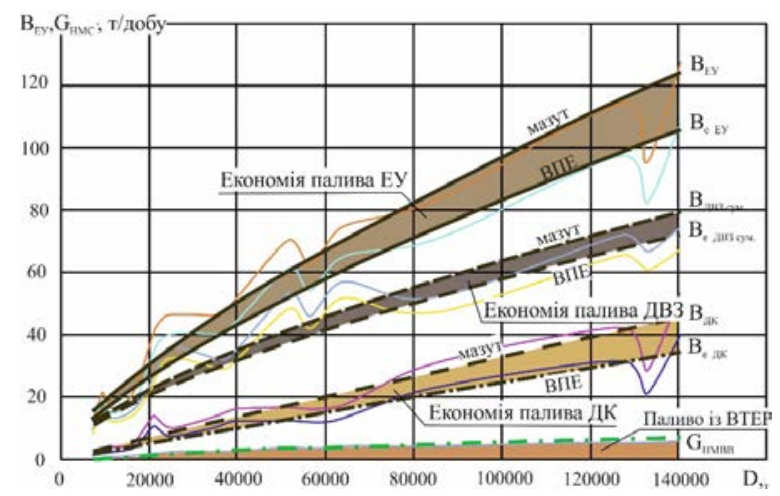

Рис. 9. Залежності витрат і економії палива від дедвейту танкерів та нафторудовозів при спалюванні ВПЕ з $\mathrm{W}^{\mathrm{r}}=30 \%$ : ДВ3 - ВПЕ (M40 + 20\% $\left.\mathrm{H}_{2} \mathrm{O}\right)$; ДК - ВПЕ (M40 + 30\% $\left.\mathrm{H}_{2} \mathrm{O}\right) ; \mathrm{B}_{\mathrm{Ey}}=0,0254 \mathrm{x}^{0,7168}, \mathrm{R}^{2}=0,9472 ; \mathrm{B}_{\mathrm{eFy}}=0,0247 \mathrm{x}^{0,7057}$, $\mathrm{R}^{2}=0,9458 ; \quad \mathrm{B}=0,0439 \mathrm{x}^{0,6328}, \quad \mathrm{R}^{2}=0,924 ;$ $\mathrm{B}=0,04 \mathrm{x}^{0,6328}, \mathrm{R}^{2}=0,924 ; \mathrm{B}_{\mathrm{AK}}=0,0006 \mathrm{x}^{0,948}, \mathrm{R}^{2}=0,9301$;

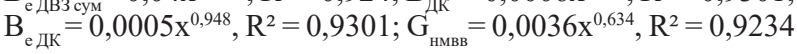




\section{ЕНЕРГЕТИЧНЕ МАШИНОБУДУВАННЯ №1-2020}

\section{ВИСНОВКИ}

1. Для підвищення економічної ефективності утилізаційних і допоміжних котлів необхідно забезпечити кавітаційну підготовку води необхідної якості (із солевмістом до 180 мг/л) зі збільшенням $\mathrm{pH}$ до 8,5 і вище, що забезпечить ефективне спалювання ВПЕ з водомісткістю $\mathrm{W}^{\mathrm{r}}=25-30 \%$.

2. Спалювання кавітаційної ВПЕ відповідної якості з водомісткістю близько $\mathrm{W}^{\mathrm{r}}=30 \%$ приводить до створення еквімолярного або близького до нього співвідношення $\mathrm{NO}_{2}$ : $\mathrm{NO}$ (одержано значення 0,35 ) в димових газах на виході із зони горіння, що забезпечуе зниження інтенсивності НТК (з 1,3 мм/рік при спалюванні мазуту $3 \alpha=1,2$ до 0,2 мм/рік при спалюванні ВПЕ 3 водомісткістю $\mathrm{W}^{\mathrm{r}}=30 \%$ навіть при $\alpha=1,5$ ).

3. Зниження інтенсивності низькотемпературної корозії забезпечує збільшення глибини утилізації в УК на 25-30\%, збільшення ККД у допоміжних котлах на 10\%, що забезпечує зменшення теплових викидів в атмосферу в 1,6 раза.

4. Використання електродіалізних опріснювачів для отримання необхідної кількості опрісненої води (ділюату i католіту) 3 установкою додаткових електродів забезпечує зменшення витрат електроенергії в 1,25 раза і можливість комплексного використання водних ресурсів на судні (забезпечується повним використанням продуктів електродіалізного опріснювання забортної води: ділюата з властивостями дистиляту - для підготовки ВПЕ, а католіту - 3 лужними властивостями для зрошення насадки скрубера $з$ метою забезпечення інтенсифікації конденсаційних процесів).
5. Розроблена технологія комплексної системи дає змогу забезпечити можливість використання теплоти конденсації пари сірчаної кислоти, а також водяної пари.

6. Застосування теплообмінних поверхонь у скруберах дасть змогу забезпечити майже 100-відсоткову утилізацію теплоти конденсації пари сірчаної теплоти i водяної пари в умовах надійної роботи конденсаційних поверхонь котлів і їх газоходів, а також газоходів до і після скруберів.

7. Розроблені конструктивні схеми допоміжних і утилізаційних котлів з установкою конденсаційних поверхонь економайзерів, гарячого теплопостачання (для конденсації пари $\mathrm{H}_{2} \mathrm{SO}_{4}$ виготовлених із вуглецевої сталі, для конденсації $\mathrm{H}_{2} \mathrm{SO}_{4} \mathrm{i}_{2} \mathrm{O}_{3}$ нержавіючої сталі) і з використанням скрубера дають змогу забезпечити підвищення ККД до 100\% (при розрахунках теплових балансів допоміжних котлів за нижчою теплотою згоряння) і до $65 \%$ глибини утилізації котлів.

8. Запропоновані схемні рішення підвищення ефективності комплексного використання паливно-енергетичних (первинних і вторинних) енергоресурсів, а також водних ресурсів суден, при спалюванні ВПЕ з водомісткістю 25-30\% на основі кавітаційно-циркуляційного способу підготовки водопаливної емульсії для енергетичних установок, із застосуванням скруберів забезпечують економію чистого палива в процесі спалювання ВПЕ в допоміжних котлах до $25 \%$, в головних двигунах і ДГ до $8 \%$, що дає змогу одержати економію палива при роботі СЕУ на рівні $10 \%$ з урахуванням використання теплоти спалювання нафтомастиломістких вод.

\section{REFERENCES}

[1] Gorbov, V. M. (2012) Al'ternativnye topliva v sudovoj jenergetike : monografija / V. M.Gorbov, V. S. Mitenkova. Nikolaev : NUK. $316 \mathrm{~s}$.

[2] Margulis, M. A. (1986) Zvukohimicheskie reakcii i sonoljuminiscencija. M. : Himija. $288 \mathrm{~s}$.

[3] Dolinskij, A. A., Basok, B. I. (2001) Diskretno-impul'snaja transformacija jenergii v adiabatno vskipajushhem potoke. Promyshlennaja teplotehnika. t. 23. № 4-5. S. 8-20.

[4] Sinajskij, N. A., Goshej, T. A. (2003) Ispol'zovanie metoda tjazheloj kavitacii dlja szhiganija mazuta i orjemul'sii. Teplojenergetika. № 5. S. 76-80.

[5] Parsadanov, I. V. Teplickij, A. A., Karjagin, I. N., Solodovnikov, V. V., Kravchenko, S. A., Hodak, P. G. (2011) Primenenie vodotoplivnoj jemul'sii v avtotraktornom dizele. Jenergeticheskie i jekonomicheskie pokazateli. (Chast' II). Dvigateli vnutrennego sgoranija, 2, 121-123.

[6] Pahomov, Ju. A. (2004) Toplivo i toplivnye sistemy sudovyh dizelej / Ju. A. Pahomov, Ju. P. Korobkov, E. V. Dmitrievskij, G. A. Vasil'ev. Pod redakciej kand. tehn. nauk. Pahomova Ju. A. M. : RKonsul't. 464 s.

[7] Scarhete, D. (2013) Diesel-water emulsion, an alternative fuel to reduce diesel engine emissions. A review. Machines. Technologies, materials. № 7. P. 13-16.

[8] Kryshtyn, L. K., Reshetnikov, I. P. (1989) Utilizacija neftjanyh ostatkov na morskih sudah. M. : Transport, 95 s.

[9] Panov, V. S. (2012) Sovershenstvovaniye sudovoy toplivnoy sistemy na osnove vikhrevogo effekta i kompleksnoy obrabotki vody dlya vodotoplivnoy emul'sii (Avtoref. dis. kand. tekhn. nauk). Volzhskaya gosudarstvennaya akademiya vodnogo transporta, Nizhniy Novgorod. S. 25.

[10] Buharkin E.N. (1997) Obespechenie nadezhnyh uslovij jekspluatacii gazootvodjashhego trakta v kotel'nyh s kondensacionnymi jekonomajzerami. Teplojenergetika. № 9. S. 23-26.

[11] Davidson, V. V., Eliseev, V. I., Tolstopjat, A. P., Tolstopjat, P. A. (2000). Szhiganie vodomazutnyh jemul'sij v teplovyh agregatah. Materialy 4-go Minskogo mezhdunar. foruma po teplomassoobmenu. T. 10, 405-412.

[12] Vorzhev, YU. I., Gimbutis, K. K. (1985) Ob ispol'zovanii vodotoplivnykh emul'siy v sudovykh dizel'nykh ustanovkakh. Sudostroyeniye. № 7. S. 18-22. 
[13] Filipshhuk, A. N. (2016) Vlijanie solesoderzhanija vody vodomazutnoj jemul'sii na skorost' nizkotemperaturnoj korrozii . Vodnij transport : Zb. naukovih prac' Kiïvs'koï derzhavnoï akademiï vodnogo transportu imeni get'mana Petra Konashevicha-Sagajdachnogo. № 2(25). S. 70-77.

[14 Kolbasenko, O. V., Dumo, B. V., Gorjachkin, A. V., Kornienko, V. S. (2018). Rezul'tati doslidzhen' niz'kotemperaturnoï koroziï pri spaljuvanni vodopalivnih emul'sij. Visnik Priazovs'kogo derzhavnogo tehnichnogo universitetu : zb. nauk. prac'. № 37 , S. 44-52.

[15] Horyachkin, V. YU., Horyachkin, A. V., Akimov, O. V., Korniyenko, V. S., Filipshchuk, O. M., Tenditnyy, YU. H. (2017). Sposib pidhotovky vodopalyvnoyi emul'siyi dlya enerhetychnykh ustanovok, v yakykh spalyuyet'sya sirchyste orhanichne palyvo. Patent Ukrayiny 115037. Kyiv : Ministerstvo ekonomichnoho rozvytku i torhivli Ukrayiny; opubl. 11.09.17. Byul. № 17.

[16] Jakubovskij, Ju.V., Sumenkov, V. M., Seleznev, Ju. S. i dr. (1991) Jekspluatacija proizvodstvennyh kotlov KVG-34K na vodotoplivnoj jemul'sii. Rybnoe hozjajstvo. № 3. S. 57-60.

[17] Shevchenko, V. V., Filipshchuk, O. M., Boboshko, I. V. (2004). Deklaratsiy patent Ukrayiny na vynakhid UA 64384 A, Elektrodializnyy aparat. Kyyiv: Derzhavnyy departament intelektual'noyi vlastnosti.

[18] Filipshchuk, O. M. (Red.),. Markov, A. E, Burenko, O. V., Subbotkina, O. P. (2019) Pidvyshchennya efektyvnosti elektrodializnoho oprisnennya shlyakhom ustanovky dodatkovykh elektrodiv. Innovatsiyi $v$ sudnobuduvanni ta okeanotekhnitsi : materialy X Mizhnarodnoyi naukovo-tekhnichnoyi konferentsiyi. u 2 tomakh. T. 1. Mykolayiv: NUK. S. 383-390.

\section{СПИСОК ВИКОРИСТАНОЇ ЛІТЕРАТУРИ}

[1] Горбов В. М. (2012) Альтернативные топлива в судовой энергетике : монография / В. М. Горбов, В. С. Митенкова. Николаев : НУК. 316 с.

[2] Маргулис М. А. (1986) Звукохимические реакции и сонолюминисценция. Москва : Химия. 288 с.

[3] Долинский А. А., Басок Б. И. (2001) Дискретно-импульсная трансформация энергии в адиабатно вскипающем потоке. Промышленная теплотехника. Т. 23. № 4-5. С. 8-20.

[4] Синайский Н. А., Гошей Т. А. (2003) Использование метода тяжелой кавитации для сжигания мазута и орэмульсии. Теплоэнергетика. № 5. С. 76-80.

[5] Парсаданов И. В., Теплицкий А. А., Карягин И. Н., Солодовников В. В., Кравченко С. А., Ходак П. Г. (2011) Применение водотопливной эмульсии в автотракторном дизеле. Энергетические и экономические показатели. (Часть II). Двигатели внутреннего сгорания, 2. С. 121-123.

[6] Пахомов Ю. А. (2004) Топливо и топливные системы судовых дизелей / Ю. А. Пахомов, Ю. П. Коробков, Е. В. Дмитриевский, Г. А. Васильев. Под редакцией канд. техн. наук. Пахомова Ю. А. Москва : РКонсульт. 464 с.

[7] Scarhete D. (2013) Diesel-water emulsion, an alternative fuel to reduce diesel engine emissions. A review. Machines. Technologies, materials. № 7. P. 13-16.

[8] Крыштын Л. К., Решетников И. П. (1989) Утилизация нефтяных остатков на морских судах. Москва : Транспорт. 95 с.

[9] Панов В. С. (2012) Совершенствование судовой топливной системы на основе вихревого эффекта и комплексной обработки воды для водотопливной эмульсии : автореф. дис. ...канд. техн. наук. Волжская государственная академия водного транспорта, Нижний Новгород. С. 25.

[10] Бухаркин Е. Н. (1997) Обеспечение надежных условий эксплуатации газоотводящего тракта в котельных с конденсационными экономайзерами. Теплоэнергетика. № 9. С. 23-26.

[11] Давидсон В. В., Елисеев В. И., Толстопят А. П., Толстопят П. А. (2000). Сжигание водомазутных эмульсий в тепловых агрегатах. Материалы 4-го Минского междунар. форума по тепломассообмену. Т. 10. С. 405-412.

[12] Воржев Ю. И., Гимбутис К. К. (1985) Об использовании водотопливных эмульсий в судовых дизельных установках. Судостроение. № 7. С. 18-22.

[13] Филипщук А. Н. (2016) Влияние солесодержания воды водомазутной эмульсии на скорость низкотемпературной коррозии. Водний транспорт : збірник наукових праць Київської державної академії водного транспорту імені гетьмана Петра Конашевича-Сагайдачного. № 2(25). С. 70-77.

[14] Колбасенко О. В., Димо Б. В., Горячкін А. В., Корнієнко В. С. (2018). Результати досліджень низькотемпературної корозії при спалюванні водопаливних емульсій. Вісник Приазовського державного технічного університету : збірник наук. праць. № 37. С. 44-52.

[15] Горячкін В. Ю., Горячкін А. В., Акімов О. В., Корнієнко В. С., Філіпщук О. М., Тендітний Ю. Г. (2017). Спосіб підготовки водопаливної емульсії для енергетичних установок, в яких спалюється сірчисте органічне паливо. Патент України 115037. Київ : Міністерство економічного розвитку і торгівлі України; опубл. 11.09.17, Бюл. № 17.

[16] Якубовский Ю. В., Суменков В. М., Селезнев Ю. С. и др. (1991) Эксплуатация производственных котлов КВГ-34К на водотопливной эмульсии. Рыєбное хозяйство. № 3. С. 57-60.

[17] Шевченко В. В., Філіпщук О. М., Бобошко I. В. (2004). Декларацій патент України на винахід UA 64384 A, Електродіалізний апарат. Київ : Державний департамент інтелектуальної властності.

[18] Філіпщук О. М. (Ред.),. Марков А. Е, Буренко О. В., Субботкіна О. П. (2019) Підвищення ефективності електродіалізного опріснення шляхом установки додаткових електродів. Інновації в суднобудуванні та океанотехніці: матеріали Х Міжнародної науково-технічної конференції у 2 томах. Т.1. Миколаїв : НУК. С. 383-390.

(C) О. М. Філіпщук, О. В. Колбасенко Дата надходження статті до редакції: 18.03.2020 Дата затвердження статті до друку: 17.04.2020 